\title{
Self-Efficacy In Online Learning Environments: A Literature Review
}

\author{
Emtinan Alqurashi, Duquesne University, USA
}

\begin{abstract}
The purpose of this paper was to examine the relationship between self-efficacy and online learning environments. Self-efficacy refers to "beliefs in one's capabilities to organize and execute the courses of action required to produce given attainments" (Bandura, 1997, p. 3). This paper reviews studies on self-efficacy in online learning environments from 1997 to 2015. Three main categories were discussed: computer self-efficacy, Internet and information-seeking self-efficacy and LMS (Learning Management Systems) self-efficacy. Possible areas of research on self-efficacy in online learning environments were suggested.
\end{abstract}

Keywords: Self-Efficacy; Computer Self-Efficacy; Internet Self-Efficacy; LMS Self-Efficacy

\section{INTRODUCTION}

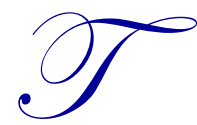

he term self-efficacy refers to "beliefs in one's capabilities to organize and execute the courses of action required to produce given attainments" (Bandura, 1997, p. 3). That is, the level of confidence that someone's have to perform a particular task, activity, action or challenge. Bandura (1994) defines self-efficacy as someone's beliefs "about their capabilities to produce designated levels of performance that exercise influence over events that affect their lives" (p. 71). Self-efficacy beliefs determine how people might feel, think, be motivated and therefore how they act and behave. According to Bandura (1997), efficacy beliefs constitute the key factor of human agency. If an individual believes that he/she cannot achieve the results, they will not make any effort to make things happen. Bandura (1997) states that self-efficacy beliefs

"influence the courses of action people choose to pursue, how much effort they put forth in given endeavors, how long they will persevere in the face of obstacles and failures, their resilience to adversity, whether their thought patterns are self- hindering or self-aiding, how much stress and depression they experience in coping with taxing environmental demands, and the level of accomplishments they realize" (p.3).

Efficacy beliefs can influence individuals to become committed to achieve their desired outcomes successfully. People who have high confidence with their capabilities are considered to have a strong sense of efficacy. They don't take difficult tasks as obstacles to avoid, but instead they take it as a challenge to develop their skills. They set challenging goals for themselves and they commit to them; and they quickly recover their sense of efficacy if they failed in a task. As a result, the level of stress and anxiety is reduced; and the amount of personal accomplishments is enhanced (Bandura, 1997). In the other hand, people who have doubts with their capabilities try to avoid difficult tasks because it can be a threat to them, and those people are considered to have low felt efficacy. Bandura (1994) described those people after facing a difficult task, "they dwell on their personal deficiencies, on the obstacles they will encounter, and all kinds of adverse outcomes rather than concentrate on how to perform successfully" (p. 2). They quickly give up when facing difficulties; and they slowly recover heir sense of efficacy if they failed in a task. They are considered as "victims" to stress and depression (Bandura, 1997).

\section{Sources of Self-Efficacy}

Bandura (1997) has introduced the theory of self-efficacy, which states that self-efficacy expectations are based on four major sources of information: (1) performance accomplishments (also called inactive mastery experience), (2) vicarious experience, (3) verbal persuasion, and (4) physiological states. These four principles are considered as the 
core elements in the development of self-efficacy in general including in the learning context. Performance accomplishments, the first source of information, are the most influential as it is based on learners' previous successful experience. Repeated successes develop strong efficacy expectation that leads to reducing the negative affect of failure. As a result, Bandura states "improvements in behavioral functioning transfer not only to similar situations but to activities that are substantially different from those on which the treatment was focused" (Bandura, 1997, p. 195). In vicarious experience, people do not depend on their successful experience as the main source of information. They tend to observe others performing an activity successfully. This can be valuable in forming beliefs in self-efficacy. Bandura (1997) has stated that in this source, learners "persuade themselves that if others can do it, they should be able to achieve at least some improvement in performance" (p. 197). So it doesn't depend on someone's capability to achieve a task but on social comparison. Therefore, self-efficacy would higher if learners were capable of achieving a task that others have done, in the other hand, self-efficacy would lower if the learners fail to meet the performance of others. Verbal persuasion, the third source of information, is commonly used because its ease and it is available. Learners see the persuader as someone who is qualified enough to provide authentic feedback. Verbal persuasion can either lead to higher self-efficacy by encouragements, or lower selfefficacy by providing unrealistic feedback. "Skilled efficacy builders encourage people to measure their success in terms of self improvement rather than in terms of triumphs over others" (Bandura, 1997, p. 106). Physiological states is the last source of information that can have direct effect on learners' self efficacy. When people judge stress and anxiety, they depend on their state of physiological arousal. Generally, It is very likely that individual will succeed if they are not in the state of aversive arousal (Bandura, 1997). Online learners are similar to traditional classroom learners in which where their self-efficacy comes from. Y.-C. Lin, Liang, Yang, and Tsai (2013) investigated the sources of Internet self-efficacy for older learners and they found that they had the similar sources of self-efficacy introduced by Bandura (1997). However, Bates and Khasawneh (2007) found that self-efficacy in the context of online learning is influenced by four factors, which are: (1) previous success with online learning, (2) pre-course training, (3) instructor feedback, and (4) online learning technology anxiety.

\section{SELF-EFFICACY IN ONLINE LEARNING ENVIRONMENTS}

Research on self-efficacy has started before online learning has occurred, between the late 1970s and the early 1990s, which was before the birth of online learning (C. B. Hodges, 2008). In 2008, Hodges stated, "research on self-efficacy in online environments is in its infancy" (p. 10). He suggested that more research is needed in the area of self-efficacy in online learning. Many of the research on self-efficacy in online learning environments was conducted in higher education, as that is not the case with research on self-efficacy in traditional learning environments.

The focus of the previous studies mostly were on the technology factor of self-efficacy in online learning, for example, computer self-efficacy (Jan, 2015; Lee \& Hwang, 2007; Lim, 2001; Pellas, 2014; Simmering, Posey, \& Piccoli, 2009; Womble, 2007; Wu, Tennyson, \& Hsia, 2010), Internet self-efficacy (Joo, Bong, \& Choi, 2000; Kuo, Walker, Belland, Schroder, \& Kuo, 2014; Kuo, Walker, Schroder, \& Belland, 2014; Y.-C. Lin et al., 2013; Womble, 2007), information-seeking self-efficacy (Hill \& Hannofin, 1997; Tang \& Tseng, 2013), and Learning Management System (LMS) self-efficacy (Martin \& Tutty, 2008; Martin, Tutty, \& Su, 2010). Other than the technology factor, some studies have focused on the learning factor alone (Artino, 2007; C. Hodges, 2008; Joo et al., 2000; Joo, Lim, \& Kim, 2013; Y.-M. Lin, Lin, \& Laffey, 2008; Shea \& Bidjerano, 2010; Xiao, 2012) and others focused on general self-efficacy in online learning environments (Gebara, 2010). Few studies are available that investigated multidimension of self-efficacy in online learning (Bates \& Khasawneh, 2007; DeTure, 2004; Fletcher, 2005; Miltiadou \& Yu, 2000; Puzziferro, 2008; Shen, Cho, Tsai, \& Marra, 2013; W Taipjutorus, 2014; W Taipjutorus, Hansen, \& Brown, 2012).

The table below summarizes some studies on self-efficacy in online learning environments between the year of 1997 and 2015. 
Table 1. Summary of research on self-efficacy in online learning environments

\begin{tabular}{|c|c|c|c|c|}
\hline Author(s) & Study & Country & Participants & Method \\
\hline $\begin{array}{l}\text { Hill and Hannofin } \\
\text { (1997) }\end{array}$ & $\begin{array}{l}\text { Metacognition, orientation, self-efficacy, } \\
\text { prior system and subject knowledge \& } \\
\text { strategies used in online learning. }\end{array}$ & US & $\begin{array}{l}15 \text { university } \\
\text { students }\end{array}$ & $\begin{array}{l}\text { Survey, think aloud } \\
\text { protocol, interview }\end{array}$ \\
\hline Joo et al. (2000) & $\begin{array}{l}\text { Self-efficacy, self-regulation \& } \\
\text { performance in web-based instruction. }\end{array}$ & $\begin{array}{l}\text { South } \\
\text { Korea }\end{array}$ & $\begin{array}{l}152 \text { junior high } \\
\text { school students }\end{array}$ & Survey \\
\hline $\begin{array}{l}\text { Miltiadou and } \mathrm{Yu} \\
(2000)\end{array}$ & $\begin{array}{l}\text { Online learning self-efficacy for } \\
\text { communication technologies. }\end{array}$ & US & $\begin{array}{l}330 \text { college } \\
\text { students }\end{array}$ & Survey via email \\
\hline $\operatorname{Lim}(2001)$ & $\begin{array}{l}\text { Computer self-efficacy, academic self- } \\
\text { concept, satisfaction, and future } \\
\text { participation of adult distance learners. }\end{array}$ & US & $\begin{array}{l}235 \text { university } \\
\text { students }\end{array}$ & $\begin{array}{l}\text { Web and listserve } \\
\text { survey }\end{array}$ \\
\hline DeTure (2004) & $\begin{array}{l}\text { Cognitive style, online technologies self- } \\
\text { efficacy \& student success in online } \\
\text { courses. }\end{array}$ & US & $\begin{array}{l}73 \text { community } \\
\text { collage students }\end{array}$ & $\begin{array}{l}\text { Paper and pencil } \\
\text { survey }\end{array}$ \\
\hline Fletcher (2005) & Learner online learning self-efficacy. & Australia & 460 students & Survey \\
\hline $\begin{array}{l}\text { Bates and } \\
\text { Khasawneh } \\
(2007)\end{array}$ & $\begin{array}{l}\text { Online learning self-efficacy, student } \\
\text { outcome expectations \& use of online } \\
\text { learning systems. }\end{array}$ & US & $\begin{array}{l}288 \text { university } \\
\text { students }\end{array}$ & Online survey \\
\hline $\begin{array}{l}\text { Lee and Hwang } \\
(2007)\end{array}$ & $\begin{array}{l}\text { Self-regulated learning strategy, computer } \\
\text { self-efficacy, system quality perception of } \\
\text { the e-Learning environment \& learners' } \\
\text { satisfaction. }\end{array}$ & $\begin{array}{l}\text { South } \\
\text { Korea }\end{array}$ & $\begin{array}{l}230 \text { university } \\
\text { students }\end{array}$ & $\begin{array}{l}\text { Analysis } \\
\text { questionnaire }\end{array}$ \\
\hline Womble (2007) & $\begin{array}{l}\text { Learner satisfaction, self-efficacy, and } \\
\text { perceived usefulness within an e-leaning } \\
\text { context. }\end{array}$ & US & $\begin{array}{l}440 \text { government } \\
\text { agency employees }\end{array}$ & Survey \\
\hline Artino (2007) & $\begin{array}{l}\text { Motivational beliefs, perceptions of the } \\
\text { learning environment and satisfaction with } \\
\text { a self-paced online course. }\end{array}$ & US & $\begin{array}{l}646 \text { students from } \\
\text { a service academy }\end{array}$ & Self-report survey \\
\hline C. Hodges (2008) & $\begin{array}{l}\text { Motivational email messages, learner self- } \\
\text { efficacy and achievement in an } \\
\text { asynchronous course. }\end{array}$ & US & $\begin{array}{l}125 \text { university } \\
\text { students }\end{array}$ & $\begin{array}{l}\text { Pretest-posttest } \\
\text { control group design }\end{array}$ \\
\hline $\begin{array}{l}\text { Y.-M. Lin et al. } \\
(2008)\end{array}$ & $\begin{array}{l}\text { Task value, self-efficacy, social ability and } \\
\text { learning satisfaction. }\end{array}$ & US & $\begin{array}{l}108 \text { university } \\
\text { students }\end{array}$ & Survey \\
\hline $\begin{array}{l}\text { Martin and Tutty } \\
(2008)\end{array}$ & $\begin{array}{l}\text { LMS self-efficacy and course performance } \\
\text { for online and hybrid learners. }\end{array}$ & US & $\begin{array}{l}69 \text { university } \\
\text { students }\end{array}$ & Survey \\
\hline Puzziferro (2008) & $\begin{array}{l}\text { Performance as a function of grade and } \\
\text { course satisfaction in online learning, } \\
\text { students' self-efficacy for online } \\
\text { technologies and self-regulated learning } \\
\text { strategies. }\end{array}$ & US & $\begin{array}{l}815 \text { community } \\
\text { college students }\end{array}$ & Questionnaire \\
\hline $\begin{array}{l}\text { Simmering et al. } \\
(2009)\end{array}$ & $\begin{array}{l}\text { Characteristics associated with effective } \\
\text { training (initial motivation to learn and } \\
\text { computer self-efficacy) and learning in a } \\
\text { self-directed online course. }\end{array}$ & US & $\begin{array}{l}190 \text { university } \\
\text { students }\end{array}$ & Self-report data \\
\hline Gebara (2010) & $\begin{array}{l}\text { General self-efficacy and course } \\
\text { satisfaction. }\end{array}$ & US & $\begin{array}{l}61 \text { university } \\
\text { students }\end{array}$ & Online survey \\
\hline $\begin{array}{l}\text { Martin et al. } \\
(2010)\end{array}$ & $\begin{array}{l}\text { Students' confidence with LMS, LMS self- } \\
\text { efficacy and course performance for e- } \\
\text { learners. }\end{array}$ & US & $\begin{array}{l}68 \text { university } \\
\text { students }\end{array}$ & Survey \\
\hline $\begin{array}{l}\text { Shea and } \\
\text { Bidjerano (2010) }\end{array}$ & $\begin{array}{l}\text { Learner self-efficacy measures and ratings } \\
\text { of the quality of learning in virtual } \\
\text { environments. }\end{array}$ & US & $\begin{array}{l}3165 \text { students } \\
\text { from } 42 \\
\text { institutions }\end{array}$ & Online survey \\
\hline Wu et al. (2010) & $\begin{array}{l}\text { Computer self-efficacy, performance } \\
\text { expectations, system functionality, content } \\
\text { feature, interaction, learning climate and } \\
\text { student learning satisfaction. }\end{array}$ & Taiwan & $\begin{array}{l}212 \text { college } \& \\
\text { university students }\end{array}$ & $\begin{array}{l}\text { Paper-based and } \\
\text { online questionnaire }\end{array}$ \\
\hline $\begin{array}{l}\text { W Taipjutorus et } \\
\text { al. (2012) }\end{array}$ & $\begin{array}{l}\text { Learner control and online learner self- } \\
\text { efficacy. }\end{array}$ & $\begin{array}{l}\text { New } \\
\text { Zealand }\end{array}$ & $\begin{array}{l}31 \text { university } \\
\text { students }\end{array}$ & Online survey \\
\hline
\end{tabular}


(Table 1 continued)

\begin{tabular}{|c|c|c|c|c|}
\hline Author(s) & Study & Country & Participants & Method \\
\hline Xiao (2012) & $\begin{array}{l}\text { Self-efficacy of online learners and } \\
\text { motivation. }\end{array}$ & China & $\begin{array}{l}20 \text { university } \\
\text { students }\end{array}$ & $\begin{array}{l}\text { Semi-structured } \\
\text { interviews }\end{array}$ \\
\hline Joo et al. (2013) & $\begin{array}{l}\text { Learners' locus of control, self-efficacy, } \\
\text { task value, learner satisfaction, } \\
\text { achievement and persistence in an online } \\
\text { university. }\end{array}$ & $\begin{array}{l}\text { South } \\
\text { Korea }\end{array}$ & $\begin{array}{l}897 \text { university } \\
\text { students }\end{array}$ & Online surveys \\
\hline $\begin{array}{l}\text { Kuo, Walker, } \\
\text { Belland, and } \\
\text { Schroder (2013) }\end{array}$ & $\begin{array}{l}\text { Interaction, Internet self-efficacy, self- } \\
\text { regulated learning \& student satisfaction in } \\
\text { online learning. }\end{array}$ & US & $\begin{array}{l}111 \text { university } \\
\text { students }\end{array}$ & Online survey \\
\hline $\begin{array}{l}\text { Y.-C. Lin et al. } \\
(2013)\end{array}$ & $\begin{array}{l}\text { Sources underlying middle aged and older } \\
\text { adults' Internet self-efficacy. }\end{array}$ & Taiwan & $\begin{array}{l}24 \text { middle aged } \\
\text { and older adults }\end{array}$ & Interview \\
\hline Shen et al. (2013) & $\begin{array}{l}\text { Online learning self-efficacy, prior online } \\
\text { experience, academic status, gender and } \\
\text { student satisfaction with online learning. }\end{array}$ & US & $\begin{array}{l}406 \text { university } \\
\text { students }\end{array}$ & Online survey \\
\hline $\begin{array}{l}\text { Tang and Tseng } \\
\text { (2013) }\end{array}$ & $\begin{array}{l}\text { Distance learners' information literacy } \\
\text { skills in using digital library resources \& } \\
\text { learners' information seeking self-efficacy. }\end{array}$ & US & 219 students & Online survey \\
\hline $\begin{array}{l}\text { Kuo, Walker, } \\
\text { Belland, et al. } \\
(2014)\end{array}$ & $\begin{array}{l}\text { Interaction, Internet self-efficacy \& } \\
\text { students' satisfaction in synchronous } \\
\text { learning environments. }\end{array}$ & Taiwan & $\begin{array}{l}57 \text { university } \\
\text { students }\end{array}$ & $\begin{array}{l}\text { Paper-based and } \\
\text { electronic survey }\end{array}$ \\
\hline $\begin{array}{l}\text { Kuo, Walker, } \\
\text { Schroder, et al. } \\
(2014)\end{array}$ & $\begin{array}{l}\text { Interaction, Internet, self-efficacy, self- } \\
\text { regulation \& student satisfaction in online } \\
\text { learning. }\end{array}$ & US & $\begin{array}{l}180 \text { university } \\
\text { students }\end{array}$ & Online survey \\
\hline Pellas (2014) & $\begin{array}{l}\text { Computer self-efficacy, metacognitive self- } \\
\text { regulation, self-esteem \& students' } \\
\text { engagement. }\end{array}$ & Greece & $\begin{array}{l}305 \text { university } \\
\text { students }\end{array}$ & Web-based survey \\
\hline $\begin{array}{l}\text { W Taipjutorus } \\
(2014)\end{array}$ & $\begin{array}{l}\text { Learner control, online learning self- } \\
\text { efficacy, age, gender, prior online } \\
\text { experience \& computer skills. }\end{array}$ & $\begin{array}{l}\text { New } \\
\text { Zealand }\end{array}$ & 75 students & Online survey \\
\hline $\operatorname{Jan}(2015)$ & $\begin{array}{l}\text { Academic self-efficacy, computer self- } \\
\text { efficacy, prior experience, and satisfaction } \\
\text { with online learning. }\end{array}$ & US & $\begin{array}{l}103 \text { university } \\
\text { students }\end{array}$ & Online survey \\
\hline
\end{tabular}

In this review, three categories regarding self-efficacy and online learning are discussed: computer self-efficacy, Internet and information-seeking self-efficacy and LMS (Learning Management Systems) self-efficacy.

\section{Computer Self-Efficacy}

Research on self-efficacy and computers is mainly related to learners' confidence in their capability of using computers and other type of technology. For example, Jan (2015) conducted a study with 103 graduate students taking online courses at a university in USA. The researcher measured academic self-efficacy, computer selfefficacy, prior experience with online learning and student satisfaction. The results of the study found a positive and significant relationship between computer self-efficacy and prior experience with online learning, and between academic self-efficacy and prior experience with online learning, and between academic self-efficacy and student satisfaction. Findings also show a positive and significant relationship between academic self-efficacy and computer self-efficacy, and between prior experience and student satisfaction. However, computer self-efficacy and student satisfaction have no positive or significant relationship. Similarly, Simmering et al. (2009) found that computer selfefficacy is not related to motivation to learn in online courses, however, computer self-efficacy was positively related to prior experience with online learning.

On the other hand, Lim (2001) found that computer self-efficacy was statistically a significant predictor of student satisfaction, and there is a positive relationship between student satisfaction and future intention to take online courses. Womble (2007) also found a significant positive relationship between computer self-efficacy and student satisfaction in online learning environments. Correspondingly, findings from another study revealed that computer self-efficacy is one of the main determinations of student satisfaction with blended e-learning system environments 
(Wu et al., 2010). Another empirical study by Pellas (2014) with 305 university students who were taking online courses, found that computer self-efficacy has a positive relationship with students' cognitive and emotional engagement factors, and a negative relationship with behavioral factors. Lee and Hwang (2007) have proposed a model for measuring e-learning effectiveness, and they suggested that computer self-efficacy is a very important and critical factor to student satisfaction with e-learning.

\section{Internet and Information-Seeking Self-Efficacy}

Research on self-efficacy and Internet is related to learners' confidence in their capability of using the Internet to seek for information; this is similar to information-seeking self-efficacy in online learning. Joo et al. (2000) investigated the relationship between Internet self-efficacy and students' performance on the written and search tests in web-based instruction. Internet self-efficacy was found to predict students' performance on the search test. However, there was no significant relationship between Internet self-efficacy and students' performance on the written test. Kuo, Walker, Schroder, et al. (2014) survey 180 undergraduate and graduate students taking online courses, they found Internet self-efficacy has a positive significant but very weak relationship with student satisfaction; however, Internet self-efficacy was not a significant predictor for student satisfaction. Similarly, Womble (2007) found a significant positive relationship between Internet self-efficacy and student satisfaction in online learning environments. A study by Kuo, Walker, Belland, et al. (2014) also found significant but weak relationship between Internet self-efficacy and student satisfaction; however, Internet self-efficacy does not predict student satisfaction in online learning environments. Seeking or searching for information in the Internet is highly related to students' perceived self-efficacy; Hill and Hannofin (1997, p. 59) found that "lack of confidence resulted in low-level searches to simply locate information" where high perceived self-efficacy leads to more exploration and locating desired information. Likewise, Tang and Tseng (2013) surveyed 219 distance learners and they found that those who have higher self-efficacy for information seeking and ability to use information showed higher selfefficacy for online learning and exhibited greater knowledge in online resources. On the other hand, distance learners who have low self-efficacy for information seeking showed more interest in learning how to use the library resources but not the strategies to use online resources.

\section{LMS Self-Efficacy}

Martin and Tutty (2008) and Martin et al. (2010) have developed an instrument to measure Learning Management System (LMS) self-efficacy, this instrument measures the confidence levels of learners with LMS and how it affect their performance. The instrument includes five technology parts: (1) assessing the course content, (2) tests and grades, (3) asynchronous communication, (4) synchronous communication, (5) Advanced tools. They found that self-efficacy of online learners was significantly higher than hybrid learners. However, LMS self-efficacy does not have a significant effect on course performance for the online learners but it had a positive influence on course performance for the hybrid learners.

\section{SUMMARY AND CONCLUSIONS}

The role of self-efficacy in online learning environments is still in need of more investigations. Computer selfefficacy had significant impact on student satisfaction with online environments and intention to take future online courses in some studies, while others showed no relationship. Internet self-efficacy predicted student performance and satisfaction with online learning but in other studies, it showed that it does not. LMS self-efficacy had no impact on performance in fully online learning environments but had impact in hybrid courses. Consequently, that there are two possible hypotheses. A possible hypothesis is that self-efficacy plays an important role in online learning; another possible hypothesis is self-efficacy does not play an important role in online learning.

Because of little research has been done to investigate the relationship between self-efficacy (other than technology factor) and online learning and because of opposing possible hypotheses. More research is needed to develop of understanding the nature of the relationship. Although computer skills, Internet skills and information-seeking skills are needed for online learning but they oversee other dimensions of online learning such as learning, interaction and collaborative skills. Those aspects together are important to consider when measuring self-efficacy in online learning. 


\section{AUTHOR BIOGRAPHY}

Emtinan Alqurashi is a doctoral student in the Instructional Technology and Leadership Program at Duquesne University. She obtained her Masters degree in Digital Technologies, Communication and Education from The University of Manchester in United Kingdom. Email: emtinan.alqurashi@gmail.com

\section{REFERENCES}

Artino, A. R. (2007). Motivational beliefs and perceptions of instructional quality: predicting satisfaction with online training. Journal of Computer Assisted Learning, 24(3), 260-270. doi:10.1111/j.1365-2729.2007.00258.x

Bandura, A. (1994). Self-efficacy. In V. S. Ramachaudran (Ed.), Encyclopedia of human behavior (Vol. 4, pp. 71-81). New York: Academic Press.

Bandura, A. (1997). Self-efficacy: The exercise of control. New York: W.H. Freeman.

Bates, R., \& Khasawneh, S. (2007). Self-efficacy and college students' perceptions and use of online learning systems. Computers in Human Behavior, 23(1), 175-191. doi:10.1016/j.chb.2004.04.004

DeTure, M. (2004). Cognitive Style and Self-Efficacy: Predicting Student Success in Online Distance Education (0892-3647). Retrieved from http://eric.ed.gov/?id=EJ683296

Fletcher, K. M. M. (2005). Self-efficacy as an evaluation measure for programs in support of online learning literacies for undergraduates. The Internet and Higher Education, 8(4), 307-322. doi:10.1016/j.iheduc.2005.09.004

Gebara, N. L. (2010). General self-efficacy and course satisfaction in online learning: A correlational study. (Doctoral dissertation), University of Missouri - Columbia. Retrieved from http://www.editlib.org/p/121111

Hill, J. R., \& Hannofin, M. J. (1997). Cognitive Strategies and Learning from the World Wide Web. Educational Technology Research and Development, 45(4), 37-64. Retrieved from http://www.jstor.org/stable/30221342

Hodges, C. (2008). Self-efficacy, Motivational Email, and Achievement in an Asynchronous Math Course. Journal of Computers in Mathematics and Science Teaching, 27(3), 265-285.

Hodges, C. B. (2008). Self-efficacy in the context of online learning environments: A review of the literature and directions for research. Performance Improvement Quarterly, 20(3-4), 7-25. doi:10.1002/piq.20001

Jan, S. K. (2015). The Relationships Between Academic Self-Efficacy, Computer Self-Efficacy, Prior Experience, and Satisfaction With Online Learning. American Journal of Distance Education, 29(1), 30-40. doi:10.1080/08923647.2015.994366

Joo, Y. J., Bong, M., \& Choi, H. J. (2000). Self-efficacy for self-regulated learning, academic self-efficacy, and internet selfefficacy in web-based instruction. Educational Technology Research and Development, 48(2), 5-17. doi:10.1007/BF02313398

Joo, Y. J., Lim, K. Y., \& Kim, J. (2013). Locus of control, self-efficacy, and task value as predictors of learning outcome in an online university context. Computers \& Education, 62, 149-158. doi:10.1016/j.compedu.2012.10.027

Kuo, Y.-C., Walker, A. E., Belland, B. R., \& Schroder, K. E. E. (2013). A predictive study of student satisfaction in online education programs. The International Review of Research in Open and Distributed Learning, 14(1), 16-39. Retrieved from http://www.irrodl.org/index.php/irrodl/article/view/1338

Kuo, Y.-C., Walker, A. E., Belland, B. R., Schroder, K. E. E., \& Kuo, Y.-T. (2014). A case study of integrating Interwise: Interaction, internet self-efficacy, and satisfaction in synchronous online learning environments. The International Review of Research in Open and Distributed Learning, 15(1), 161-181. Retrieved from http://www.irrodl.org/index.php/irrodl/article/view/1664

Kuo, Y.-C., Walker, A. E., Schroder, K. E. E., \& Belland, B. R. (2014). Interaction, Internet self-efficacy, and self-regulated learning as predictors of student satisfaction in online education courses. The Internet and Higher Education, 20, 35-50. doi:10.1016/j.iheduc.2013.10.001

Lee, J.-K., \& Hwang, C.-Y. (2007). The effects of computer self-efficacy and learning management system quality on eLearner's satisfaction. In L. Cameron, A. Voerman, \& J. Dalziel (Eds.), Proceedings of the 2007 European LAMS Conference: Designing the future of learning (pp. 73-79). Greenwich: LAMS Foundation.

Lim, C. K. (2001). Computer self-efficacy, academic self-concept, and other predictors of satisfaction and future participation of adult distance learners. American Journal of Distance Education, 15(2), 41-51. doi:10.1080/08923640109527083

Lin, Y.-C., Liang, J.-C., Yang, C.-J., \& Tsai, C.-C. (2013). Exploring middle-aged and older adults' sources of Internet selfefficacy: A case study. Computers in Human Behavior, 29(6), 2733-2743. doi:10.1016/j.chb.2013.07.017

Lin, Y.-M., Lin, G.-Y., \& Laffey, J. M. (2008). Building a Social and Motivational Framework for Understanding Satisfaction in Online Learning. Journal of Educational Computing Research, 38(1), 1-27. doi:10.2190/EC.38.1.a

Martin, F., \& Tutty, J. I. (2008). Learning Management System Self-Efficacy of online and hybrid learners: Using LMSES Scale. Paper presented at the Proceeding of the UNC Teaching and Learning with Technology Conference, Raleigh, NC.

Martin, F., Tutty, J. I., \& Su, Y. (2010). Influence Of Learning Management Systems Selfefficacy On E-Learning Performance. $i$ manager's Journal on School Educational Technology, 5(3), 26-35. Retrieved from http://www.imanagerpublications.com/Archives.aspx 
Miltiadou, M., \& Yu, C. H. (2000). Validation of the Online Technologies Self-Efficacy Scale (OTSES). Paper presented at the AECT International Convention, Denver CO.

Pellas, N. (2014). The influence of computer self-efficacy, metacognitive self-regulation and self-esteem on student engagement in online learning programs: Evidence from the virtual world of Second Life. Computers in Human Behavior, 35, 157170. doi:10.1016/j.chb.2014.02.048

Puzziferro, M. (2008). Online Technologies Self-Efficacy and Self-Regulated Learning as Predictors of Final Grade and Satisfaction in College-Level Online Courses. American Journal of Distance Education, 22(2), 72-89. doi:10.1080/08923640802039024

Shea, P., \& Bidjerano, T. (2010). Learning presence: Towards a theory of self-efficacy, self-regulation, and the development of a communities of inquiry in online and blended learning environments. Computers \& Education, 55(4), 1721-1731. doi:10.1016/j.compedu.2010.07.017

Shen, D., Cho, M.-H., Tsai, C.-L., \& Marra, R. (2013). Unpacking online learning experiences: Online learning self-efficacy and learning satisfaction. The Internet and Higher Education, 19, 10-17. doi:10.1016/j.iheduc.2013.04.001

Simmering, M. J., Posey, C., \& Piccoli, G. (2009). Computer Self-Efficacy and Motivation to Learn in a Self-Directed Online Course. Decision Sciences Journal of Innovative Education, 7(1), 99-121.

Taipjutorus, W. (2014). The relationship between learner control and online learning self-efficacy. (Doctoral dissertation), Massey University, Manawatu Campus, New Zealand.

Taipjutorus, W., Hansen, S., \& Brown, M. (2012). Investigating a relationship between learner control and self-efficacy in an online learning environment. Journal Of Open, Flexible, and Distance Learning, 16(1), 56-69.

Tang, Y., \& Tseng, H. W. (2013). Distance Learners' Self-efficacy and Information Literacy Skills. The Journal of Academic Librarianship, 39(6), 517-521. doi:10.1016/j.acalib.2013.08.008

Womble, J. C. (2007). E-learning: The Relationship Among Learner Satisfaction, Self-efficacy, and Usefulness. (Doctoral disertation), Alliant International University, San Diego. Retrieved from http://books.google.com/books?id=oSyz3R5YTAIC

Wu, J.-H., Tennyson, R. D., \& Hsia, T.-L. (2010). A study of student satisfaction in a blended e-learning system environment. Computers \& Education, 55(1), 155-164. doi:10.1016/j.compedu.2009.12.012

Xiao, J. (2012). Successful and unsuccessful distance language learners: an 'affective' perspective. Open Learning: The Journal of Open, Distance and e-Learning, 27(2), 121-136. doi:10.1080/02680513.2012.678611 
NOTES 